\title{
INDIREGT LIABILITIES OF CONSTRUCTION LENDERS IN A DEVELOPMENT SETTING
}

\section{The GroundWork}

Lending institutions often find themselves as players in the following scenario:

A developer, $D$, is interested in acquiring and developing a parcel of unimproved land, 200 acres in size. $D$ has applied to a bank or savings and loan association for a loan to finance the acquisition and construction. The lending institution has essentially three responses. ${ }^{1}$ Perhaps finding the venture too risky from a credit standpoint, it may decide to reject the loan application. Alternatively, the lender may offer only a construction loan, forcing $D$ to look elsewhere, probably to the owner of the parcel, ${ }^{2}$ for land financing. Finally, the institution may be sufficiently convinced of the soundness of the venture that it agrees to finance both acquisition and construction.

This Comment is concerned with the lender's second and third responses, notably some of the adverse consequences of those financing decisions. The existence of some potential liability in connection with construction loans is, of course, of no surprise to lending institutions. They are familiar with "direct liabilities" imposed when a developer-borrower alleges an illegality in the loan transaction and brings a claim under the Consumer Credit Protection Act (Truth-in-Lending Act) ${ }^{3}$ or state usury laws. ${ }^{4}$ This form of liability

1 A fourth alternative, to finance only the land acquisition, would be unattractive both to the institutional lender and to the developer. The developer would have difficulty finding a separate source of construction financing unless the initial land acquisition mortgage were subordinated to any such construction loan. Yet, the institutional lender, in all likelihood, would be unwilling to agree to subordinate its claim and thereby to decrease substantially its chances of recovery of the loan. The institutional lender, financing only land acquisition, thus would be cutting off alternative sources of construction funding in an effort to protect its interest in what would probably remain unimproved land. See, e.g., Housing Mortgage Co. v. Allied Construction, Inc., 374 Pa. 312, 97 A.2d 802 (1953).

2 An agreement might be reached with the owner of the parcel for its sale to the developer in exchange for the latter's execution of a purchase money mortgage. The owner, unhampered by the institutional lender's credit policies, see note 1 supra, should thus be more willing to subordinate his claim to the institutional lender's construction loan, relying on the increased value of the improved land for security.

315 U.S.C. $\$ \$ 1601-1691$ (1976).

4 E.g., Cat. Bus. \& Prof. Code § 10242 (West Supp. 1964-78); Pa. Stat. ANN. tit. 41, 502 (Purdon Supp. 1972-77). 
should be contrasted with that which is the subject of this Comment, a less apparent "indirect" liability sought to be imposed by ultimate consumers, not parties to the original loan transaction. ${ }^{5}$ The typical scenario involves an injured or defrauded home or lot purchaser who claims that the developer-borrower has been negligent or guilty of a statutory violation. The purchaser contends also that the construction lender be held liable because of its independent failure to detect and correct the developer's errors. Such "indirect" liability presumes a duty owed by the lender to the borrower's customer and requires that there be negligent breach of that duty by the lender before recovery is allowed. Indirect liability is thus to be distinguished from the concept of vicarious liability or strict liability without fault.

This characterization of indirect liability is sufficient to identify three potential sources of such liability in current law: one arising from the common law of torts, the others appearing in statutory context in the securities laws ${ }^{6}$ and in the Interstate Land Sales Full Disclosure Act (Land Sales Act). ${ }^{7}$ Common law liability, the firstborn, can be traced to a 1968 decision by the California Supreme Court, Connor v. Great Western Savings and Loan Association. ${ }^{8}$ A case of first impression, Connor considered whether a construction lender might be liable to home purchasers for defects in the improvements it had financed. ${ }^{9}$ Finding a potential for such liability, Chief Justice Traynor, speaking for the court, seemed preoccupied with and surprised by the extent of the defendant construction lender's involvement in the development project and termed it "an active participant in a home construction enterprise" whose financing

5 There is sometimes a second loan from the construction lender to the consumer that provides long-term financing for purchase of the home; however, as will be seen later, this is not a necessary condition for indirect lender liability. See text accompanying note 36 infra.

6 Securities Act of 1933, 15 U.S.C. $\$ \$ 77 a-77$ aa (1976); Securities Exchange Act of 1934, 15 U.S.C. $\$ \$ 78 \mathrm{a}-78 \mathrm{kk}$ (1976).

715 U.S.C. $\$ \$ 1701-20$ (1976).

869 Cal. 2d 850, 447 P.2d 609, 73 Cal. Rptr. 369 (1968) (4-3 decision).

9 The homeowners charged the construction lender with failure to recognize and correct the developer's negligent construction. An additional claim might be brought against the developer on a theory of express or implied warranty of habitability. Such a claim, however, is not easily combined with one for lender liability. In a warranty claim, plaintiffs assert only an unfulfilled promise and present no proof that the developer could or should have discovered a given defect. A lender liability claim, on the other hand, is grounded in negligent supervision. Plaintiffs in a construction defects case would thus face the difficult task of proving that the lender should have discovered a defect although there is in fact no indication that the developer could have detected the difficulty. It is not surprising that claims of indirect lender liability have been commonly accompanied by assertions of builder negligence rather than warranty claims. 
"took on ramifications beyond the domain of the usual money lender." 10 The court's discussion of the lender's participation in the construction project raises the crucial question: was the lender's involvement as extraordinary as the court seemed to believe? If so, then the holding in Connor must be read narrowly, limiting liability to such instances of "unusual" lender participation.11 A plausible argument exists, however, that the lender's participation in Connor was not so unusual and that construction-lender involvement routinely takes on "ramifications beyond the domain of the usual money lender." "12 Under this view, Connor identifies a duty of care that might be imposed on all construction lenders. Case-by-case adjudication comparing levels of construction-lender participation, then, seems irrelevant. Whatever the relative merits of these arguments, however, the narrow interpretation has prevailed. ${ }^{13}$ The decision has been interpreted as differentiating, in terms of potential liability, among varying degrees of constructionlender involvement. Therefore, wittingly or not, the decision of the California Supreme Court has transformed the matter of construction-lender participation into the critical element in the liability controversy.

The decade since the Connor case has seen judicial and legislative responses to the issue of indirect lender liability, with numerous suits by purchasers of defectively constructed homes. ${ }^{14}$ Paralleling this common law question are recent federal decisions struggling with essentially the same issues of indirect liability and requisite level of construction-lender participation in a statutory framework. To understand the problem in this context, return for a moment to the loan-transaction scenario outlined at the beginning

$10 \mathrm{Id}$. at 864,447 P.2d at $616,73 \mathrm{Cal}$. Rptr. at 376.

11 For commentary supporting such a narrow reading, see, e.g., Bartlett \& Lapatin, The Status of a Creditor as a "Controlling Person", 28 MERCER L. Rev. 639,647 (1977) [hereinafter cited as Bartlett \& Lapatin]; Gutierrez, Liability of a Construction Lender Under Civil Code Section 3434: An Amorphous Epitaph to Connor v. Great Western Savings \& Loan Association, 8 PAc. L.J. 1, 5 (1977) [hereinafter cited as Gutierrez]. An earlier and slightly more expansive view is provided in Comment, New Liability in Construction Lending: Implications of Connor v. Great Western Savings \& Loan, 42 S. CAL. L. REv. 353 (1969) [hereinafter cited as S. Cax. Comment].

$12 \mathrm{~S}$. CAL. Comment, supra note 11 , at 354 , quoting Connor v. Great Western Sav. \& Loan Ass'n, 69 Cal. 2d 850, 864, 447 P.2d 609, 616, 73 Cal. Rptr. 369, 376 (1968). The author insists, "The significant point is that while Great Western participated in the enterprise more than the 'usual money lender,' it probably did not participate significantly more than the usual construction lender." Id. 354.

13 See text accompanying notes $41-53$ infra. 53 infra.

14 See CAI. Civ. CodE $\$ 3434$ (West 1970). For examples of cases, see note 
of this discussion. Assume that $D$ has borrowed construction and perhaps land-acquisition funds as well and is proceeding with work on the 200-acre parcel. Rather than await completion of the homes, he simultaneously undertakes a sales campaign, offering tenacre unimproved lots to the public. ${ }^{15}$ Depending upon the nature of his development and sales effort, $D$ may be subject to the various registration and disclosure requirements and fraud provisions of the securities laws and Land Sales Act. ${ }^{16}$ The sales campaign may promise amenities, such as golf courses, swimming pools, and clubhouses, that fail in the end to materialize. The defrauded lot purchasers will then seek to recover their lost investment by alleging misrepresentations or omissions with respect to the nature of the community or as to the developer's financial position. As in the cases of construction-defects disputes, the developer's omissions or misrepresentations may pave the way for indirect lender liability. Because the chances of recovery of monetary damages from the builder of an unsuccessful residential development are remote, ${ }^{17}$ plaintiffs frequently seek to hold the lending institution jointly liable. The parallels between common law and statutory litigation instituted by consumers against construction lenders go further. A plaintiff relying on the statutes again must prove more than the mere existence of a construction loan from the lending institution to the developer. He must allege that the lender is liable for fraud as an "aider and abettor" under the Land Sales Act ${ }^{18}$ or as a "controlling person" under the Securities Exchange Act of 1934.10 This, in turn, invites some courts to focus again on evidence of additional participation by the lender in the development enterprise. Although some courts have resisted this temptation and

15 For purposes of common law liability, construction may precede or follow purchase of the lot. Statutory liability is, however, more likely to arise with the sale of an unimproved lot in a planned, heavily advertised development. The developer will often accelerate sales of such lots to provide ready cash. A lot purchaser will transfer to the developer a down payment and an installment contract or promissory note for the balance. These notes or contracts will in turn be purchased at a discount by a lending institution. The developer thus has his cash and the lender a long-range profit. See Timmreck v. Munn, 433 F. Supp. 396 (N.D. Ill. 1977), discussed at notes 79-85 infra, for such a scenario.

16 See notes 6 \& 7 supra; see also text accompanying notes 69-74 \& 94-123 infra for discussion of the applicability of the relevant statutes.

17 For a discussion of the typical developer, small and under-capitalized, see Lefcoe \& Dobson, Savings Associations as Land Developers, 75 YALE L.J. 1271 (1966).

18 See Timmreck v. Munn, 433 F. Supp. 396, 405-07 (N.D. Ill. 1977) (defendant bank could be held an "aider and abettor" under the Act).

19 See Fuls v. Shastina Properties, Inc., 448 F. Supp. 983, 989-90 (N.D. Cal. 1978) (defendant lender was not a "controlling person" under the 1934 Act). 
insisted on proof of the lender's "knowing" assistance in the fraud, at least one court ${ }^{20}$ has echoed Connor and suggested that the criterion for statutory liability may be whether or not the lending institution "exceeded the normal scope of financing practices" and "actively participated" in the developer's venture. ${ }^{21}$

The first portion of this Comment will review decisions addressing construction-lender liability in both the statutory and common law contexts in order to delineate the current bounds of potential liability. After identifying the limits of constructionlender liability under current law, the Comment will evaluate what has been reported. The critical question is whether the existing framework for determining lender liability, with its emphasis on level of participation and economic benefit, is theoretically or practically satisfactory. In concluding that it is not, the Comment will argue that these two factors should be discarded as largely irrelevant to a sound theory of indirect lender liability. In their place, the Comment proposes that a lender's capacity for control of the builder's allegedly culpable conduct must be established before liability resting on negligent supervision may be imposed. ${ }^{22}$

Building an alternative framework around this concept of control, the Comment explores the circumstances in which a construction lender can supervise effectively the allegedly culpable conduct of the developer-borrower. In the course of this examination, it poses three sets of questions. First, do current practices of the lender indicate that supervision of a particular aspect of the developer's conduct is feasible? Second, how heavy a burden of liability will a lender be compelled to bear? Are there mechanisms by which the construction lender can insure compliance by the developer? Can the costs of liability be spread? Finally, what impact will construction-lender liability have on the housing industry?

The final portion of the Comment employs this framework to reassess the potential for lender liability under the Land Sales Act and the securities laws, and in the context of common law liability for construction defects. It concludes that the potential statutory liability of construction lenders should be quite limited because the capacity for lender supervision of a developer's selling operations is insufficient to warrant liability except in a narrow set of circumstances. Use of the alternative framework proffered in this Comment identifies those circumstances and avoids the broad, open-ended

20 Timmreck v. Munn, 433 F. Supp. 396 (N.D. Ill. 1977).

21 Id. 406.

22 See note 135 infra \& accompanying text. 
implications of Timmreck $v$. Munn. ${ }^{23}$ The Comment arrives at a conclusion less favorable to construction lenders, however, in the context of common law liability. There, the courts thus far have been unwilling to hold lenders liable for defective construction. Despite the broad implications of the Connor decision, subsequent courts have found liability to be justified only in instances of extraordinary lender involvement in the development project. By looking instead to the concept of control, this Comment identifies considerable capacity for lender supervision of the developer's allegedly culpable conduct and, therefore, significant potential for lender liability. Once again, the Comment notes answers to the series of questions suggested by this alternative framework that are determinative: first, most construction lenders currently have the capacity to inspect for structural defects; second, there are mechanisms by which construction lenders may secure compliance on the part of the developer and thereby reduce their own burdens of liability; third, such safeguards may permit the imposition of lender liability in this limited context without unduly constricting the housing industry. Further empirical study of market impact is recommended.

\section{The Current Potential for Indirect Lender Liability}

\section{A. Liability for Construction Defects}

1. The Connor Decision-Birth of the Participation Criterion

Although the logical starting point for a consideration of lender liability for construction defects, Connor v. Great Western Savings and Loan Association, ${ }^{24}$ has been reviewed and commented upon extensively, ${ }^{25}$ some understanding of its complex factual setting is essential for a proper examination of the level of participation requisite for liability.

Two inexperienced developers, desiring to purchase and develop a large tract of land in the Conejo Valley, approached Great Western Savings and Loan Association for help in financing the

23433 F. Supp. 396 (N.D. IIl. 1977).

2469 Cal. 2d 850, 447 P.2d 609, 73 Cal. Rptr. 369 (1968).

25 See, e.g., Bartlett \& Lapatin, supra note 11; Gutierrez, supra note 11; Lender Liability for Construction Defects, 5 Real Prop. Proв. Tr. J. 495 (1970); Lubell, Changes in Construction Lenders Policies-1959-1969, A Lenders Viewpoint [sic], 44 L.A. BAR Bucx. 348 (1969) [hereinafter cited as Lubell]; Comment, The Expanding Scope of Enterprise Liability, 69 CoLun. L. REv. 1084, 1090-96 (1969); S. CAL. Comment, supra note 11; Comment, Liability of the Institutional Lender for Structural Defects in New Housing, 35 U. CHI. L. REv. 739 (1968) [hereinafter cited as U. CFI. Comment]. 
$\$ 340,000$ purchase price for the first hundred-acre parcel. ${ }^{26}$ Under the resulting arrangement, an early example of "land warehousing," ${ }^{27}$ Great Western provided the last $\$ 150,000$ of the purchase price and took title to the land, granting the developers a one-year option to repurchase the land in three parcels for the sum of $\$ 180,000$; thus, what was in substance a loan to the developers could be treated, under this scheme, as a statutorily sanctioned real estate investment by the savings and loan association. ${ }^{28}$ In addition, Great Western was afforded the opportunity to realize a $\$ 30,000$ capital gain on resale of the land to the developers. ${ }^{29}$ In return for its $\$ 150,000$ "Ioan," Great Western also secured the right to make construction loans for the homes on the hundred-acre parcel as well as the right of first refusal to make long-term "end loans" to prospective home purchasers. $^{30}$ Construction financing was in turn conditioned upon the presale of a specified number of lots. When this presale requirement was satisfied, $\$ 3,000,000$ in construction loans were disbursed according to a predetermined schedule. ${ }^{31}$

26 Connor v. Great Western Sav. \& Loan Ass'n, 69 Cal. 2d 850, 858, 447 P.2d 609, 612, 73 Cal. Rptr. 369, 372 (1968).

27 "Under such an arrangement, a financial institution holds land for a developer until he is ready to use it. Unlike a normal bailee of personal property, however, the institution retains title to the property as well as the right to possession." Id. at 859,447 P.2d at 613,73 Cal. Rptr. at 373 .

28 Id. Great Western was faced with a statutory prohibition against lending outright more than $33 \mathrm{I} / 3$ percent of the appraised value of the improved land. The "warehousing" scheme was clearly designed to circumvent this statutory obstacle. This statute has since been amended to permit loans up to 70 percent of the appraised value of unimproved land. CAL. FIN. CoDE $\$ 7155$ (West Supp. 1968-78).

2969 Cal. 2 d at 864,447 P.2d at $617,73 \mathrm{Cal}$. Rptr. at 377. Subsequent courts have relied upon this financing scheme to distinguish Connor from other factual settings. E.g., Bradler v. Craig, 274 Cal. App. 2d 466, 79 Cal. Rptr. 401 (1969). The Connor court itself focused on the "warehousing" plan as evidence of Great Western's substantial economic benefit and its extraordinary level of involvement in the development project. Great Western obviously benefited from its resale of the parcel to the developers; it is less clear, however, how the additional involvement or profit actually increased Great Western's capacity for supervision of the construction. As one considers the other evidence of "unusual" lender involvement mentioned by the Connor court, one must keep in mind the same crucial question: Does this additional involvement increase the lender's ability to recognize and correct defective construction?

$30 \mathrm{~A}$ one percent fee was charged for loans made on behalf of qualified buyers and a one-and-a-half percent fee for those purchasers regarded as poor credit risks. Additionally, Great Western's right of first refusal as to such loans afforded it ten days to meet any competitor's proposed financing terms. If the terms were met and the buyer still placed the loan elsewhere, the developers were obliged to pay Great Western the fees and interest obtained by the other lending institution. Great Western in fact provided end loans to most of the Conejo Valley home buyers. Connor v. Great Western Sav. \& Loan Ass'n, 69 Cal. 2d 850, 861, 447 P.2d 609, 614, 73 Cal. Rptr. 369, 374 (1968).

31 Advances on these construction loans and "land draws," lump sums calculated as a percentage of the appraised value of the land, were apparently used by 
The developers were undercapitalized, however, a condition of which Great Western was aware, ${ }^{32}$ causing them to cut corners by purchasing plans and specifications prepared for other projects and to ignore recommendations made by their own soil engineers. ${ }^{33}$ Having thus failed to provide for the peculiar characteristics of the soil, the developers found, two years later, that heavy rains loosened the soil, destroying several of the houses.

The principal question for the California Supreme Court was whether the lending institution might be liable to the home buyers for such defective construction. ${ }^{34}$ Though summarily rejecting the buyers' argument that Great Western was vicariously liable as a participant in a joint venture or joint enterprise along with the developers, ${ }^{35}$ the court agreed that Great Western was potentially liable for breach of an independent duty of care owed to the buyers. In concluding that such a duty of care existed, the majority relied on a six-part test:

"The determination whether in a specific case the defendant will be held liable to a third person not in privity is a matter of policy and involves the balancing of various factors, among which are [1] the extent to which the transaction was intended to affect the plaintiff, [2] the foreseeability of harm to him, [3] the degree of certainty that the plaintiff suffered injury, [4] the closeness of the connection between the defendant's conduct and the injury suffered, [5] the moral blame attached to the defend-

the developers to pay the $\$ 180,000$ due Great Western in their exercise of the option to repurchase the hundred-acre tract. Id.

32 The Court referred to Great Western's preliminary investigation of the developers' financial condition, an inquiry which had uncovered evidence of the latter's tenuous position. The majority opinion also noted a financial statement fled by the development company listing capital of $\$ 325,000$, of which $\$ 320,000$ was accounted for as estimated profits from the yet-to-be completed sale of homes. Such an entry was described as "far outside the bounds of generally accepted accounting principles." Id. at 860, 447 P.2d at 613, 73 Cal. Rptr. at 373. But see Lubell, supra note 25 , at $349-50$.

33 Connor v. Great Western Sav. \& Loan Ass'n, 69 Cal. 2d 850, 864 n.7, 447 P.2d 609, 616 n.7, 73 Cal. Rptr. 369, 376 n.7 (1968).

34 The lower court had rendered a judgment of nonsuit in favor of Great Western, Connor v. Conejo Valley Dev. Co., 61 Cal. Rptr. 333 (1967).

$35 \mathrm{~A}$ joint venture exists when there is "an agreement between the parties under which they have a community of interest, that is, a joint interest, in a common business undertaking, and understanding as to the sharing of profits and losses, and a right of joint control. ..." Although the profits of [Great Western and the developers] . . . were dependent on the overall success of the development, neither was to share in the profits or the losses that the other might realize or suffer. . . U Under these circumstances, no joint venture existed.

Connor v. Great Western Sav. \& Loan Ass'n, 69 Cal. 2d 850, 863, 447 P.2d 609, 615, 73 Cal. Rptr. 369, 375 (1968) (citations omitted). 
ant's conduct, and [6] the policy of preventing future harm." 36

Chief Justice Traynor found in the construction-loan agreement an intention that the transaction affect the plaintiffpurchasers, the first element of the court's test. Great Western was willing to commit the construction funds only with assurances that residential construction would be undertaken, that a specified number of homes had been presold, and that home buyers would be channeled to its door for long-term financing. Further, the court held that the developers' inexperience and thin capitalization were reasonably foreseeable to Great Western. The "onerous" ${ }^{37}$ financing arrangements which Great Western placed on the developers increased the likelihood that the developers would be compelled to cut corners in construction.

With respect to the proximity of the plaintiffs' injury to Great Western's conduct, Chief Justice Traynor concluded that the construction lender "not only financed the development of the [hundred-acre] tract but controlled the course it would take. Had it exercised reasonable care in the exercise of its control, it would have discovered that the pre-packaged plans purchased by [the developers] required correction and would have withheld financing until the plans were corrected." 38

The court found that substantial moral blame attached to Great Western's conduct for two reasons: it breached a duty to its own shareholders when it neglected to protect the value of the security on which its loans rested, the newly constructed homes, and it carelessly administered the loan transactions despite knowledge "that the usual buyer of a home is ill-equipped with experience or financial means to discern such structural defects." 39 Finally, the court found that any rules which tended to discourage misconduct would be particularly appropriate when applied to such an established industry. ${ }^{40}$

The response to Connor has been to construe the holding quite narrowly, although Chief Justice Traynor's balancing test would of itself seem to offer a significant potential for liability on the

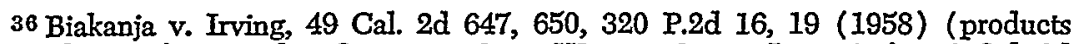
liability decision), quoted in Connor v. Great Western Sav. \& Loan Ass'n, 69 Cal. 2d 850, 865, 447 P.2d 609, 617, 73 Cal. Rptr. 369, 377 (1968).

37 Connor v. Great Western Sav. \& Loan Ass'n, 69 Cal. 2 d 850, 866, 447 P.2d $609,617,73$ Cal. Rptr. 369, 377 (1968).

$38 \mathrm{Id}$. at $867,447 \mathrm{P} .2 \mathrm{~d}$ at $618,73 \mathrm{Cal}$. Rptr. at 378 (footnote omitted).

$39 I d$.

$40 I d$. 
part of construction lenders. The California legislature sought to limit construction-lender liability to instances in which "loss or damage is a result of an act of the lender outside the scope of the activities of a lender of money or unless the lender has been a party to misrepresentations with respect to such real or personal property." 41 As might be expected, however, a formula limiting liability to acts "outside the scope of the activities of a lender of money" has done little to clarify the common law standard of Connor. Thus, courts in California, as elsewhere, have continued to use Great Western's involvement as the threshold for identifying impermissible lender activity. ${ }^{42}$

\section{Imposition of a Duty to Inspect Because of Substantial Levels of Participation}

One of the principal questions before subsequent courts has been whether lenders have a duty to inspect. In Connor, Great Western's failures to require soil tests, to examine the developers' prepackaged plans, and to inspect for gross structural defects ${ }^{43}$ were held to be actionable. Later courts, however, have been unwilling to identify a similar duty of inspection. In Callaizakis v. Astor Development Co., ${ }^{44}$ condominium purchasers and owners sought to hold several defendants, including the construction lender, liable for structural defects. The plaintiffs asserted that the defendant savings and loan association had employed its own architects and engineers to inspect the construction and, as a result, had "assumed a duty to the plaintiffs to inspect the premises in a careful manner so as to detect defective workmanship and materials and to so inform plaintiffs prior to their payment and taking of possession." 45 The court rejected the argument that inspection activities conducted by a lending institution are necessarily undertaken for the benefit of third parties rather than for its own protection; it thus established a rebuttable presumption that a con-

41 Car. Crv. Code $\$ 3434$ (West 1970).

42 E.g., Fox v. Carskadon Financial Corp. v. San Francisco Fed. Sav. \& Loan Ass'n, 52 Cal. App. 3d 484, 125 Cal. Rptr. 549 (1975). See Gutierrez, supra note 11 , at 9-12, for an informative discussion of the legislative history of section 3434 of the CACIFORNIA CrVI CODE. The author is highly critical of reverting to the Connor standard since he views the statute as completely superseding Connor. Id. 11-12.

43 Great Western had relied upon government building inspectors to discover any structural defects. Connor v. Great Western Sav. \& Loan Ass'n, 69 Cal. 2d 850, 865, 447 P.2d 609, 616-17, 73 Cal. Rptr. 369, 376-77 (1968).

444 Ill. App. 3d 163, 280 N.E.2d 512 (1972) (complaint dismissed).

$45 I d$. at 165,280 N.E.2d at 514. 
struction lender conducts periodic inspections solely for its own protection. Under ordinary circumstances, therefore, inspection activities would not give rise to a duty to safeguard the interests of home buyers. ${ }^{46}$

The court in Callaizakis drew support for its conclusion from Bradler v. Craig, ${ }^{47}$ California's second skirmish with indirect lender liability. Reading the decision in Connor as imposing liability only when a construction lender becomes "an active participant" 48 in a development project, the court of appeals struggled to identify the requisite level of involvement. In Bradler, the plaintiffs alleged that the Santa Barbara Savings and Loan Association (1) had approved construction plans, specifications, and methods; (2) had inspected and approved the completed homes; and (3) had failed to make adequate repairs though aware of the expansive character of the soil.49 The court concluded that no cause of action existed against the lender because "Santa Barbara's alleged participation was that of the usual and ordinary construction and purchase money lender, content to lend money at interest on the security of real property. Approval of plans and specifications, and periodic inspection of houses during the construction is normal procedure for any construction money lender." 50 Thus, absent the type of intricate participation and sheer economic power demonstrated by Great Western in Connor, ${ }^{51}$ or any specific evidence that inspection activities were undertaken for the benefit of a third party, ${ }^{52}$ con-

46 This Comment, focusing on potential lender liability to home and lot purchasers, does not address whether a lending institution might be liable to its own shareholders for failure to inspect adequately a construction project. Chief Justice Traynor strongly implied in Connor that such a liability would exist. Connor v. Great Western Sav. \& Loan Ass'n, 69 Cal. 2d 850, 864-65, 447 P.2d 609, 616-17, 73 Cal. Rptr. 369, 376-77 (1968).

47274 Cal. App. 2d 466, 79 Cal. Rptr. 401 (1969).

$48 \mathrm{Id}$. at $474,79 \mathrm{Cal}$. Rptr. at 407.

$49 \mathrm{Id}$. at 474-75, $79 \mathrm{Cal}$ Rptr. at 407.

$50 \mathrm{Id}$. at $475,79 \mathrm{Cal}$. Rptr. at 407 . decisive:

51 The court in Bradler found absence of involvement of the following sort

Unlike Connor, it [the lender] was not financing the development of a large tract wherein it sought to receive substantial fees for making construction loans. Unlike Connor, it did not receive a fee for "warehousing" the land. Unlike Connor, it received no guarantee from loss of profits in the event a home buyer sought permanent financing elsewhere. Unlike Connor, it was not "pre-occupied with selling prices and sales."

Id. (citations omitted).

52 Cf. Sunrise Fed. Sav. and Loan Ass'n v. Golding, No. $78-4832$ (N.Y. Sup. Ct., Suffolk Cty., Aug. 11, 1978) (court implied that duty of care owed by lender to purchaser would be created where original loan agreement between lender and builder contained explicit warranties, guarantees, or even promises to inspect and purchaser then assumed construction mortgage by extension agreement). 
struction lenders will apparently not be held liable to home purchasers for negligent inspection. ${ }^{53}$

In fact, research has uncovered no cases in which the degree or character of lender participation and benefit can actually be said to approximate that present in Connor, with the result that subsequent plaintiffs have been uniformly unsuccessful. Notably lacking has been evidence of lenders' "warehousing" of land or agreements conditioning construction loans on profits from purchase money mortgages. In Callaizakis, for example, the Illinois court refused to infer the existence of a loan fee or right of first refusal on mortgage loans to condominium purchasers. ${ }^{54}$ In Christiansen $v$. Philcent Corporation, ${ }^{55}$ plaintiff home buyers alleged that the construction lender had provided final mortgages to many of the purchasers and, moreover, had been aware of the thin capitalization of the developers. ${ }^{56}$ The Pennsylvania court found that the complaint

53 See, e.g., Meyers v. Guarantee Sav. \& Loan Ass'n, 79 Cal. App. 3d 307, 144 Cal. Rptr. 616 (1978); Bradler v. Craig, 274 Cal. App. 2d 466, 79 Cal. Rptr. 401 (1969); Callaizakis v. Astor Dev. Co., 4 Ill. App. 3d 163, 280 N.E.2d 512 (1972); Sunrise Fed. Sav, and Loan Ass'n v. Golding, No. 78-4832 (N.Y. Sup. Ct., Suffolk Cty., Aug. 11, 1978); Schenectady Sav. Bank v. Bartosik, 77 Misc. 2d 837, 353 N.Y.S.2d 706 (1974). Cf. Perez v. United States, No. 78-1107 (Ist Cir. Mar. 15, 1979) (summary judgment for defendant government proper in personal injury action where HUD found to have owed no duty of care to plaintiffs; HUD's right to inspect site did not give rise to such a duty); Armetta v. Clevetrust Realty Investors, 359 So. 2d 540 (Fla. Dist. Ct. App. 1978) (provisions in mortgage for inspection by financer of condominium project do not create duty of care on part of lender to others); Rice v. First Fed. Sav. and Loan Ass'n of Lake County, 207 So. 2d 22 (Fla. Dist. Ct. App. 1968) (no implied contractual duty to inspect for benefit of purchasers even though lender deducted from loan proceeds a fee for "inspection and supervision"); Snyder v. First Fed. Sav. \& Loan Ass'n, 241 N.W.2d 725 (S.D. 1976) (no duty to inspect mobile home for defects in workmanship where lender's level of participation did not reach that in Connor).

Even though courts have been reluctant to infer a duty of care from the right to inspect construction sites, institutions should be cautioned against neglecting inspection efforts altogether. Of the above cases, only in Snyder did the construction lender entirely refrain from any inspection. In all other instances, the lender undertook at least a cursory investigation to protect its security interest. One may only speculate whether a court might give home buyers a cause of action against a construction lender who entirely ormitted to inspect the ongoing construction.

544 Ill. App. 3d 163, 169 n.1, 280 N.E.2d 512, 516 n.I (1972). Plaintiffs in these recent cases appear at a disadvantage when compared to the home buyers in Connor. Many of the cases after Connor have been appeals from dismissals of complaints; thus, there has been no opportunity for discovery. In contrast, the California Supreme Court in Connor had access to a lower court trial transcript as well as to discovery testimony when it offered its detailed description of Great Western's involvement in the development project. Yet, despite the apparent inequity, the court in Callaizakis rejected the plaintiffs' offer to provide additional evidence of the lender's involvement after an opportunity to conduct discovery. Id.

55226 Pa. Super. 157, 313 A.2d 249 (1973).

56 The plaintiffs also alleged that the lender's participation in the project was made known to them by posters and pamphlets displayed in the sales office proclaiming the lender's involvement in other successful housing projects in the area. 
fell "far short of alleging an arrangement as interrelated as the one in Connor." ${ }^{27}$ Christiansen's significance is clouded, however, because plaintiffs were suing on a contract; the court refused to speculate whether its decision would have been the same had the buyers proceeded on a tort theory. ${ }^{58}$

A few courts, however, have chosen to extract a second, subsidiary motif from Connor-foreseeability of the harm-and have used that as an alternate basis for their decisions in favor of construction lenders. In Callaizakis, for instance, the court supplemented its earlier discussion of the defendant lender's participation by recalling the inexperience and undercapitalization of the developers in Connor and noting that Great Western's awareness of those facts had created a foreseeable risk of shoddy construction. ${ }^{50}$ Absent similar evidence that defective construction should have been foreseen, the lender in Callaizakis would not, the court determined, be liable to the condominium purchasers. ${ }^{60}$

An analogous argument was offered by a California court in Fox \& Carskadon Financial Corp. v. San Francisco Federal Savings do Loan Association, ${ }^{61}$ where construction of an apartment complex was not completed and foreclosure by a construction lender had terminated a syndicate's equity interest in the project. The syndicate claimed that the lender knew of their interest and yet negligently made a loan for construction despite a likelihood of bankruptcy on the part of the borrower. Finding the lender's activity too restricted to satisfy the Connor standard, the court also found no foreseeable risk of failure since the lender had made the loan relying on its past successful dealings with the builder. Moreover, unlike the low-income purchasers in Connor, the plaintiff syndicate was viewed as capable of undertaking its own investigation of the builder's financial stability. ${ }^{62}$

The Fox and Callaizakis courts' digressions on foreseeability reinforce the notion that Connor's applicability generally has been limited to its own factual setting. The single exception to this pattern is the decision of the Wisconsin Supreme Court in Kornitz

The argument that they had thus relied on the "reputation and expertise" of the lender was rejected, however. No participation had been specified in the posters and pamphlets beyond that of construction financing. Id. at 164, 313 A.2d at 252. 57 Id.

58 Id. at 161 n.3, 313 A.2d at 250 n.3.

59 See text accompanying note 37 supra.

604 Ill. App. 3d at 168, 280 N.E.2d at 515-16.

o1 52 Cal. App. 3d 484, 125 Cal. Rptr. 549 (1975).

62 Id. at $487,125 \mathrm{Cal}$. Rptr. at 551. 
v. Earling of Hiller, Inc. ${ }^{63}$ Kornitz, like Fox, involved a situation in which the proposed construction was never completed. The plaintiff, the purchaser of two apartment house projects, contended that an interim mortgage lender was negligent in disbursing construction funds to general contractors without first assuring itself that the labor and materials had, in fact, been applied to or set aside for the projects. ${ }^{64}$ Aware of Connor and the trend towards relaxing privity requirements in tort law, the Wisconsin court found the complaint sufficient to state a cause of action. It agreed with the plaintiff's contention that " "whether [the lender] will be held liable to a third person is determined on a case to case basis, with policy considerations the decisive factor." " 65 Because of the inadequate record, the judges remanded the case for a "fair and complete evaluation of the policy considerations involved." 66 The trial court on remand would quite possibly have focused on the level of lender involvement as determinative of liability, but, by ordering a trial and use of a balancing test, the Kornitz court at least departed from other post-Connor cases in which the presence of extraordinary lender participation was an essential allegation of the complaint. Kornitz suggests at least the possibility that a suit brought by a disappointed purchaser alleging negligent disbursement of construction funds might be litigated without regard to the extent of lender involvement in the project.

With Kornitz recognized as the exception, then, the majority of cases subsequent to Connor have discounted any general application that decision might have had. Although some decisions, notably Fox and Callaizakas, have looked to matters of feasibility and plaintiff's diligence, ${ }^{67}$ the threshold question in each of these cases has been the extent of lender participation and economic benefit, a standard which this Comment in part III proposes to replace.

\section{B. Statutory Liabilities}

The common law of liability for construction defects has had ten years to develop and to consider the ramifications of the Connor

6349 Wis. $2 d$ 97, 181 N.W.2d 403 (1970).

64 Kornitz should be distinguished from the numerous mechanics' lien disputes. See, e.g., Comment, Mechanics Liens and Surety Bonds in the Building Trades, 68 Yace L.J. 138 (1958). There, the issue is normally one of competing claims for priority between subcontractors and construction lenders. Here, the issue involves potential liability of a lender for damages arising from the purchase of unsatisfactorily completed or incomplete construction projects.

65 Kornitz v. Earling \& Hiller, Inc., 49 Wis. 2d 97, 102, 181 N.W.2d 403, 406 (1970), citing appellants' reply brief.

66 Id. at 103,181 N.W.2d at 406.

67 See text accompanying notes 61 \& 62 supra. 
decision. Nevertheless, the path of statutory liability of construction lenders, arising within the context of sales of unimproved lots, ${ }^{68}$ is not so clear: there are comparatively few cases addressing the issue. Yet, a review of the potential for liability of construction lenders under the various statutes is useful both to note the current uncertainty within the circuits and to complete the groundwork for an evaluation of the participation criterion.

\section{Land Sales Act}

The Interstate Land Sales Full Disclosure Act (Land Sales Act) ${ }^{69}$ represents the congressional response to the problems of incomplete and inaccurate disclosure in real estate transactions. The target of the statute is fraudulent offering of unimproved land rather than negligent construction or defective improvements of the sort which generated Connor and its progeny. ${ }^{70}$ The question

68 See text accompanying notes 15 \& 16 supra.

6915 U.S.C. $\$ \$ 1701-20$ (1976).

70 Case \& Jester, Securities Regulation of Interstate Land Sales and Real Estate Development-A Blue Sky Administrator's Viewpoint: Part II, 7 URB. LAw. 385, 400-08 (1975); Krasnowiecki, Townhouses with Home Associations: A New Perspective, 123 U. PA. L. Rev. 701, 706 (1975). The Act aims at protecting purchasers of properties which are advertised and/or sold through interstate commerce. See 15 U.S.C. $\$ 1703$ (a) (1976). Because of the frequent interstate aspects of their promotion, the Act has special relevance to large-scale resort and recreational properties. However, because of certain exemptions codified in 15 U.S.C. $\$ 1702$ (1976), the statute is not applicable to all real estate developments. For example, it covers only projects of fifty or more unimproved lots. 15 U.S.C. $\$ 1702(\mathrm{a})(1)$ (1976). More ambiguous has been the statutory exemption for sales of land under a contract obligating the seller to erect a building there within two years. 15 U.S.C. $\$ 1702$ (a) (3) (1976). Although this so-called "homebuilder's exemption" initially might seem to exclude most residential construction and thereby sharply limit the scope of the Land Sales Act, actually the section has not operated to keep many cases out of court. The exemption clearly does not reach instances where land is purchased as an investment, not with any intention of building, but merely with the expectation of rapid appreciation in value. See, e.g., McCown v. Heidler, 527 F.2d 204, 211 (10th Cir. 1975); Fuls v. Shastina Properties, Inc., 448 F. Supp. 983 (N.D. Cal. 1978). Also subject to the Act are those contracts which do not set a completion date notwithstanding that the building might have been completed within two years. See Nargiz v. Henlopen Developers, 380 A.2d 1361 (Del. 1977). Most importantly, it has been pointed out that the homebuilder's exemption may not even exempt the standard contract for the sale of a home in a new subdivision, which does mention construction of a home by a certain date. See Krasnowiecki, supra at 746 . According to Krasnowiecki, such contracts rarely, if ever, affirmatively obligate the builder to build and complete a home within a period of time. They do say "that the builder will sell and the buyer will buy a home if it is completed on a certain date, and if it is not completed the contract is at an end and the buyer's deposit will be returned to him." Id. This "age-old practice," Krasnowiecki concludes, does not fall within the terms of the exemption provided by section $1702(\mathrm{a})(3)$; indeed, such conditional sales were never intended to come within the scope of the Act. The effect of the language of the exemption is to "open Pandora's box" and make "practically every homebuilder in the country [subject to] the Act if he is building 
posed in this context is whether lenders owe to ultimate consumers a duty to try to arrest a developer's fraud. Specifically, the Land Sales Act requires that a statement of record, disclosing certain information about the property to be sold, must be filed by the developer with the Department of Housing and Urban Development (H.U.D.). The same information is provided to potential buyers in property reports. ${ }^{71}$ Section 1709 of the Act subjects developers and their agents to private actions by lot purchasers for any false statements or omissions of material facts in either of the reports, or for violation of the Act's general antifraud provision. ${ }^{72}$ The Act is by its terms directed to developers and their agents. ${ }^{73}$ It specifically protects lenders from direct liability in section 1702(a) (5) by exempting from coverage "the sale of evidences of indebtedness secured by a mortgage or deed of trust on real estate," unless "adopted for the purpose of evasion of this chapter." 74 The question remains whether the Act may ever be applied to impose indirect liability upon financial institutions when their developer-borrowers defraud customers.

Early attempts to bring lending institutions under the Act were uniformly unsuccessful. One court refused to permit an action against a banking corporation which had purchased installment notes secured by deeds of trust on the property absent evidence that the purchase was undertaken for the purpose of evading the Act or that the defendant had participated in any sales opera-

fifty homes or more and using the mails or other instrumentalities of commerce to advertise." Id.

A new homebuilder's exemption may have appeared recently in another guise in section 1702(b) added by the Housing and Community Development Amendments of 1978, Pub. L. No. 95-557, §907, 92 Stat. 2127 (1978). This provision provides an exemption for the sale of real estate located within a municipality or county whose governing body already specifies minimum standards for the development of subdivision lots taking place within its boundaries. In order for a developer to qualify for this exemption, he must also deliver a warranty deed to the purchaser within 180 days after the signing of the sales contract and either have extended water, sewage, and electricity lines to the lot by the time of closing or arranged for the local government to install such facilities within 180 days.

71 I5 U.S.C. $\$ 1704,1707$ (1976).

72 Id. $\$ \$ 1703 \& 1709$.

73 Id. The Act defines these terms:

(4) "developer" means any person who, directly or indirectly, sells or leases, or offers to sell or lease, or advertises for sale or lease any lots in a subdivision.

(5) "agent" means any person who represents, or acts for or on behalf of, a developer in selling or leasing, or offering to sell or lease any lot or lots in a subdivision ....

Id. $\S 1701(4) \&(5)$.

74 Id. $\$ 1702(\mathrm{a})(5)$. See Timmreck v. Munn, 433 F. Supp. 396, 406 (N.D. Ill. 1977), and cases cited therein. 
tions. ${ }^{75}$ In two actions growing out of another development scheme, plaintiff lot purchasers sought to hold Westinghouse Credit Corporation (WCC) liable as a developer or joint venturer. Again, liability as a developer was rejected without evidence of sales activity on the part of WCC. ${ }^{78}$ An agreement with the developers that WCC accept an existing portfolio of land sales contracts for previously sold lots and make direct loans to subsequent lot purchasers created, in the court's view, "only the relationship of lender and borrower." 77 The theory that WCG's status as first lienholder had generated a property interest sufficient to cast it as a joint venturer was similarly rejected. ${ }^{78}$

The first recognition of the potential liability of lenders was the 1977 decision of a federal district court in Timmreck v. Munn.79 There, the court refused to dismiss an action against a bank which had allegedly "financed the project by purchasing the plaintiff's [sic] promissory notes secured by their mortgages." 80 The court relied in part on the Tenth Circuit's expansive view of the Land Sales Act in McCown v. Heidler, ${ }^{81}$ which authorized an action for aiding and abetting under the Act against individual defendants, "be they officers, directors, or participating planners." 82 Although aware of the previous decisions dismissing complaints against construction lenders, the Timmreck court, in effect turning

75 Bettis v. Lakeland, Inc., 402 F. Supp. 1300 (E.D. Tenn. 1975).

76 Zachery v. Treasure Lake of Ga., Inc., 374 F. Supp. 251 (N.D. Ga. 1974); Adema v. Great Northern Dev. Co., 374 F. Supp. 318 (N.D. Ga. 1973). 1974).

77 Zachery v. Treasure Lake of Ga., Inc., 374 F. Supp. 251, 253 (N.D. Ga.

The court also accepted WCC's disclaimer as reproduced in its loan agreement: " Other than providing financing to facilitate your purchase of the land, Westinghouse Credit Corporation is in no way related to the development of the project or the sale of the lots, and makes no representations with respect to the land or its suitability for any purpose." Id.

78 Adema v. Great Northern Dev. Co., 374 F. Supp. 318, 319 (N.D. Ga. 1973). 79433 F. Supp. 396 (N.D. Ill. 1977).

80 Id. 399.

Unlike the development scheme in Connor where much of the sales activity awaited completion of the homes, most sales here were of unimproved land. The lot buyers in Timmreck furnished down payments and promissory notes to the developer, who then sold these notes to the lending institution for the ready cash needed for construction. The role of the lender was thus actually that of construction financer.

81527 F.2d 204 (10th Cir. 1975). While acknowledging that the Land Sales Act lacked a controlling person clause, the McCown court was nevertheless concerned that the developers and agents might be judgment proof, thus leaving victims remediless. To effectuate the Act's remedial purposes, the Tenth Circuit construed it flexibly. Id. 206-07. For an indication that the circuit has retreated from its position in McCown, see Woodward v. Terracor, 574 F.2d 1023 (10th Cir. 1978), discussed at note 113 infra.

82 Id. 207. 
such precedents on their heads, stated that those cases revealed that "the courts will make inquiries into the extent of the financing institution's participation in the project." 83 Indeed, by implying that the level of lender involvement was critical, the Timmreck opinion moved in the direction of the common law analysis developed by Connor and its progeny. The court concluded: "The plaintiffs are therefore entitled to attempt to show that the Bank exceeded the normal scope of financing practices and actively participated in and aided the advancement of a fraudulent scheme, or otherwise assisted in the luring of purchasers for an allegedly dubious project." ${ }^{84}$

Continental Bank had asserted in reply to the complaint that its only significant agreement with the developers was to purchase the secured promissory notes of qualified lot owners. Yet, according to the court, this constituted an interest in the success of the project because increased lot sales translated into profits from loans secured by the real estate. The court also refused to accept as complete the bank's characterization of its involvement: further clarification was needed with respect to the extent of Continental's participation in the planning of the project and preparation of the statement of record for H.U.D., and in the developers' sales activity. Finally, it remained unresolved whether the bank had held itself out as the financial backer of the project. The court found at least a preliminary indication of such backing in Continental's agreement with the developers to purchase the owners' promissory notes. ${ }^{85}$ In any case, the court decided sufficient evidence of lender involvement was present to warrant a trial on that issue, and it denied the bank's motion for dismissal of the complaint.

Two other courts have recently addressed claims that lending institutions be held liable as aiders and abettors under the Land Sales Act. In each instance, the court refused to find liability on the facts before it. Paralleling judicial reaction to the Connor decision, these courts appeared reluctant to impose liability yet

83433 F. Supp. at 406 .

84 Id.

85 The court pointed to $\$ 5(\mathrm{~b})$ of the agreement as implying that Continental would accept no

"obligation to purchase notes of lot owners unless the developer has continued and is continuing to complete all improvements of the Candlewick Lake Subdivision, including (without limitation) the dam, lake, association, club and utilities, within the periods set forth in Exhibit 3 hereto, and it appears that there are sufficient funds available to complete the improvements."

Id. (footnote omitted). The court speculated that such language might have assured prospective buyers that the bank had confidence in the project. 
refused to preclude this possibility in a more extreme set of circumstances. The Third Circuit, in Bartholomew v. Northampton National Bank of Easton, ${ }^{86}$ refrained from determining whether an aiding and abetting claim against lending institutions is available to defrauded lot purchasers. ${ }^{87}$ The Bartholomew court read McCown ${ }^{88}$ as authorizing liability with proof of the lenders' " $k n o w-$ ing assistance of or participation in a fraudulent scheme." " 89 The plaintiffs had contended that the defendant banks, aware of the developers' omissions and misrepresentations, had by their inaction aided and added a sense of legitimacy to a fraudulent scheme. Relying largely on the defendants' uncontradicted affidavits, the Third Circuit found no convincing proof of the lenders' knowledge and therefore dismissed the complaint. ${ }^{00}$ Similarly, in Fuls v. Shastina Properties, Inc.,91 the court applied McCown and required a similar showing of knowing assistance of or participation in a fraudulent scheme. ${ }^{92}$ As in Bartholomew, the Shastina court found no factual dispute warranting a trial on this issue.

In contrast to the "knowing assistance of or participation in" standard of Bartholomew and Shastina, the Timmreck court focused almost exclusively on the extent of Continental Bank's participation in the project, seeming not to require direct evidence of lender knowledge of fraudulent activity. The court may have been prepared to infer such awareness from the bank's alleged involvement in the planning of the project and preparation of the official filings. Such charges of participation at that early and critical stage, coupled with allegations that the bank held itself out as the financial backer of the enterprise, thus distinguish Timmreck from Bartholomew and Shastina ${ }^{93}$ and may explain the different out-

86584 F.2d 1288 (3d Cir. 1978).

87 The district court had denied the existence of an aiding and abetting claim under the Land Sales Act. That court disputed the analogy made by plaintiffs and by the court in McCown v. Heidler, 527 F.2d 204 (10th Cir. 1975), to section 10(b) of the Securities Exchange Act of 1934, 15 U.S.C. $\$ 78 j(b)$ (1976). While the 1934 Act's general antifraud provision applies to "any person" engaging in prohibited activities in connection with the sale of securities, the Land Sales Act applies by its terms only to developers and their agents. This, the district court noted, was evidence of a narrower congressional purpose which prohibited application of the Land Sales Act to a broad range of participants. 584 F.2d at 1294.

88 See text accompanying notes 81 \& 82 supra.

89584 F.2d 1288, 1294 (3d Cir. 1978), quoting McCown v. Heidler, 527 F.2d 204, 207 (10th Cir. 1975), quoting Kerbs v. Fall River Indus., Inc., 502 F.2d 731, 740 (10th Cir. 1975).

$90584 \mathrm{~F} .2 \mathrm{~d}$ at 1294.

91448 F. Supp. 983 (N.D. Cal. 1978).

92 Id. 990.

93433 F. Supp. 396, 406 (N.D. Ill. 1977). In Bartholomew, the defendant lenders participated only to the extent of accepting the assignment of purchasers" 
comes. Indeed, future cases may limit Timmreck, like Connor, to its own facts: the dearth of cases addressing aiding and abetting claims under the Land Sales Act makes any conclusions necessarily tentative. However, if Timmreck's exceedingly broad language is construed as extending liability for a developer's fraud to any lender who has a major economic interest in a project and participates in its promotion, then a substantial potential for liability exists under the Land Sales Act.

\section{The Securities Acts}

Any probe into the potential indirect liability of construction lenders under the securities acts ${ }^{94}$ is necessarily speculative. Lot purchasers have rarely utilized the federal securities laws in an attempt to reach construction lenders. ${ }^{95}$ In Fuls $v$. Shastina Properties, Inc., ${ }^{96}$ defrauded buyers contended that the lending institution was a "controlling person" under section 20(a) ${ }^{97}$ for purposes of liability under section 10(b) of the Securities Exchange Act of 1934.98 The court rejected the buyers' controlling person theory even though the lender "periodically received financial statements and sales reports, and occasionally inspected construction and development work," 99 and it found no evidence that the lender "acted in bad faith or that [it] directly or indirectly induced Shastina Properties to make the alleged fraudulent misrepresentations" as required under the Ninth Circuit's test for controlling person liability. ${ }^{100}$ No similar claim has yet been based on the securities laws' aider and abettor doctrine.

This failure to make such claims does not, however, imply that they are without merit. Necessarily antecedent to application of the

installment or promissory notes. $584 \mathrm{~F} .2 \mathrm{~d}$ at 1291 . One of the banks supplemented this role by holding a mortgage on at least part of the project. Id. In Shastina, the institution made a loan secured by a deed of trust on the property and by accounts receivable. $448 \mathrm{~F}$. Supp. at 989 . No evidence was offered in either case showing that the lenders had promoted the project or helped draft the original plans and documents.

94 Securities Act of 1933, 15 U.S.C. $\$ \$ 77 a-77 a a ~(1976)$; Securities Exchange Act of 1934,15 U.S.C. $\$ \$ 78 \mathrm{a}-78 \mathrm{kk}$ (1976).

95 See Woodward v. Terracor, 574 F.2d 1023, 1024 (10th Cir. 1978); Fuls v. Shastina Properties, Inc., 448 F. Supp. 983 (N.D. Cal. 1978).

96448 F. Supp. 983, 989-90 (N.D. Cal. 1978).

97 I5 U.S.C. $\$ 78 t(a)$ (1976). See generally Comment, Secondary Liability of Controlling Persons Under the Securities Acts: Toward an Improved Analysis, 126 U. PA. L. REv. 1345 (1978) [hereinafter cited as U. PA. Comment].

9815 U.S.C. $\$ 78 \mathrm{j}(\mathrm{b})$ (1976). This claim paralleled the aiding and abetting claim under the Land Sales Act. See text accompanying notes 91-93 supra.

99448 F. Supp. at 989.

100 Id. 990. 
securities laws to consumer real estate transactions is the question if a security is involved: more precisely, can a land sales contract constitute an "investment contract"? The Supreme Court, in United Housing Foundation, Inc. v. Forman, ${ }^{101}$ seemed to lay that question to rest when it announced that the defrauded buyer must show a "reasonable expectation of profits." 102 By focusing on profit expectations, the Court created an investment/consumption dichotomy whereby the ordinary home buyer concerned primarily with a place to live probably would fall on the consumption side of the line and thus be unprotected by the securities acts. However, some recent decisions indicate that Forman has not foreclosed application of securities law to sales of unimproved lots in an incomplete real estate development. ${ }^{103}$ Accordingly, indirect liability claims against

101421 U.S. 837 (1975).

102 Id. 852. See, e.g., Note, Securities Regulation-United Housing Foundation, Inc. v. Forman: The Supreme Court Refines the Howey Formula, 54 N.C. L. REv. 731 (1976). In Forman the Supreme Court addressed claims by residents of a large housing cooperative. Faced with a rental charge substantially above that originally advertised, residents brought suit alleging violations of section 17 (a) of the Securities Act of 1933,15 U.S.C. $\$ 77 \mathrm{q}(\mathrm{a})$ (1976), and rule $10 \mathrm{~b}-5$ of the Securities Exchange Act of 1934, 17 C.F.R. \$240.10b-5 (1977). They charged that the informational bulletin circulated to prospective purchasers of "stock" in the housing cooperative had misrepresented that the contractor would bear any cost overruns and had failed to disclose material facts about the developers. The primary question for the Court was whether the shares of stock, entitling purchasers to an apartment lease and to voting rights in the cooperative, were "securities" as defined in the federal securities laws.

The Court's holding that the shares were not "securities" within the Acts turned on its characterization of an "investment contract," which is one element of the statutory definition of a security. 15 U.S.C. $\$ 77 \mathrm{~b}(1)$ (1976). Applying Justice Murphy's test in SEC v. W.J. Howey, 328 U.S. 293 (1946), for distinguishing investment contracts from other commercial transactions, the Court inquired "whether the scheme involves an investment of money in a common enterprise with profits to come solely from the efforts of others." Id. 301. The Court found the element of profits lacking in Forman. A "reasonable expectation of profits" in the form of "either capital appreciation resulting from the development of the initial investment, .. . or a participation in earnings resulting from the use of investors' funds" was a necessary premise for an investment contract. 421 U.S. at 852 . This sort of investment decision was to be distinguished from any consumer transaction "motivated by a desire to use or consume the item purchased." Id. 852-53. The leasing agreements in the housing cooperative were of the latter sort. Although nominally involving the purchase of stock, the plaintiff residents "were attracted solely by the prospect of acquiring a place to live and not by financial returns on their investments." Id. 853.

103 The factual setting of the Forman decision is critical. There, the plaintiffs, residents in a large low-income housing cooperative, were firmly entrenched in their apartments as they complained of rental increases, 421 U.S. at 844 . Later courts have been asked to find an "investment contract" where the consumption motive of the plaintiffs is less clear. Purchasers of lots in large recreational or residential developments have instituted the more recent suits, claiming to have bought their unimproved lots with the expectation that they would rapidly appreciate in value. Characteristically, the sales campaigns promise the construction of a variety of amenities as a "common enterprise": swimming pools, golf courses, sand beaches, snowmobile trails. When these amenities fail to materialize, the lot buyers face a 
construction lenders may be forthcoming if courts continue to take a broad view of the securities laws. To the extent that securities claims against construction lenders can be expected to become more prevalent, the discussion in part III of the appropriate standard for lender liability is once again relevant.

The notion that investment contracts, as defined in Forman, do exist in the context of real estate development finds support in the recent cases upholding complaints against developers under the securities acts. ${ }^{104}$ These cases tie the investment potential of any publicly owned amenities to the land sale contract by which a single lot is acquired.105 The courts in Timmreck v. Munn ${ }^{108}$ and McCown v. Heidler ${ }^{107}$ focused on the price paid for the land. Evidence that the purchase price of the unimproved lot would be inappropriate absent the promised amenities weighed in favor of finding the land sales contract an investment rather than a consumption decision. ${ }^{108}$ These cases, however, are perhaps most noteworthy for their concentration on the seller's efforts. Timmreck, McCown, and, most recently, Anderson v. Grand Bahama Development Co. ${ }^{109}$ all seem quite willing to infer an investment motive from the promotional emphasis of the developer. The "terms of the offer," the "plan," and any "economic inducements" are all relevant to the determination of whether the sale of a "security" was

substantial decrease in the value of their lots. In this setting, an investment/ consumption dichotomy is less helpful. Because the project lies incomplete, lot owners can argue that they never intended to build or to use the lot for consumption purposes. The lot purchase was an investment, the intent being to resell at a profit when community development, notably the completion of the promised amenities, drove prices upward.

104 McCown v. Heidler, 527 F.2d 204 (10th Cir. 1975) (plaintiffs permitted to amend complaint to allege that they relied on the promotional and managerial efforts of the developer for the appreciation of their investment); Fogel v. Sellamerica, Ltd., 445 F. Supp. 1269, $1277-78$ (S.D.N.Y. 1978) (defendant's motion for summary judgment denied; trial court must consider motivation of the purchaser and promotional emphasis of the developer); Timmreck v. Munn, 433 F. Supp. 396 (N.D. Ill. 1977) (defendant's motion for summary judgment denied; court held that not only the terms of the contract, but also the specific oral and written misrepresentations made in advertising materials should be reviewed); Anderson v. Grand Bahama Dev. Co., [1979] 6 Hous. \& Dev. Rep. (BNA) 834 (IIl. App., Dec. 22, 1978); cf. Tober v. Charnita, Inc., 58 F.R.D. 74 (M.D. Pa. 1973) (dicta requiring that a factual hearing must be held in order to determine whether a cause of action under the Securities Acts exists against the promoter of recreational lots); Lowery v. Ford Hill Investment Co., 556 P.2d 1201, 1204-06 (Colo. 1976) (Howey test used to conclude that Colorado Securities Act encompasses a real estate transaction).

105 See note 103 supra.

106433 F. Supp. 396 (N.D. Ill. 1977).

107527 F.2d 204 (10th Cir. 1975).

108 Id. 211; 433 F. Supp. at 403.

109 [1979] 6 Hous. \& Dev. Rep. (BNA) 834 (Ill. App., Dec. 22, 1978). 
involved.110 Thus, any evidence of training sessions emphasizing real estate as an investment ${ }^{111}$ or specific language to the same end in sales brochures ${ }^{112}$ might persuade a court that the securities acts are applicable. Conversely, some other cases indicate that courts which choose to focus on the express obligations of the developer in the land sales contract are much less likely to find the existence of an investment contract. ${ }^{113}$

Thus, while decisions like Timmreck and Anderson cannot be characterized as a trend, they do indicate that the federal securities laws may not be as unavailable to purchasers in real estate developments as was believed at the time of the Forman decision. If securities actions proliferate, it would not be surprising for lending institutions to find themselves as parties defendant. ${ }^{114}$ However, the standards which courts are likely to apply in any trial on the merits should make recovery against the lenders unlikely. In order to

110 Timmreck v. Munn, 433 F. Supp. 396, 401 (1977).

111527 F.2d at 209-10.

112 Id. 210; 433 F. Supp. at 402-03.

113 See Woodward v. Terracor, 574 F.2d 1023 (10th Cir. 1978); Joyce v. Ritchie Tower Properties, 4.17 F. Supp. 53 (N.D. Ill. 1976); Davis v. Rio Rancho Estates, Inc., 401 F. Supp. 1045 (S.D.N.Y. 1975); and Happy Investment Group v. Lakeworld Properties, Inc., 396 F. Supp. 175 (N.D. Cal. 1975). The decision in Woodward is significant in that it signals a retreat within the Tenth Circuit from its earlier stance in McCown. Purporting to resolve a question of law, the Woodward opinion concludes that, where there is no common enterprise and no reliance on the developer's managerial efforts indicated in the sales contract, "the expectation of a profit on resale is insufficient to transform what is essentially a sale of real property into the sale of an investment contract." 574 F.2d at 1026. McCown was distinguished as merely permitting plaintiffs to file an amended complaint and to try to show at trial that defendants were under a "contractual promise" to perform certain enumerated tasks, thereby enhancing the value of individual lots. Id. However, such a reading of McCown overlooks the considerable attention that decision paid to the plaintiffs' motives and the non-contractual representations in the defendant's brochures and oral promotions. Despite this apparent misreading of McCown, however, it appears that the Tenth Circuit after Woodward will require that plaintiffs alleging a "common enterprise" and reliance on the developer's managerial efforts identify in the sales contract an express promise to construct amenities.

As recently as December, 1978, however, an Illinois appellate court signaled the continuing vitality of the McCown position when it reaffirmed that not only the terms of the contract but also the specific promotional representations can be used to show the existence of an investment contract. See Anderson v. Grand Bahama Dev. Co., [1979] 6 Hous. \& Dev. Rep. (BNA) 834 (IIl. App., Dec. 22, 1978).

The Supreme Court's latest pronouncement on the statutory definition of a "security," in Int'l Brotherhood of Teamsters v. Daniel, 99 S. Ct. 790 (1979), does not resolve the issue in a real estate context. Applying the Forman standard, the Court in Daniel excluded pension funds from the scope of the securities laws because of the absence of a true "exchange" or substantial profit. Such elements are, however, more readily identfiable in real estate transactions, as the McCown and Timmreck decisions indicate.

114 See Fuls v. Shastina Properties, Inc., 448 F. Supp. 983 (N.D. Cal. 1978), and text accompanying notes 96-100 supra. In Woodward v. Terracor, 574 F.2d 1023 (10th Cir. 1978), several lenders were joined as defendants; the issue of their liabllity was not addressed, however. 
impose indirect liability upon a construction lender under the general antifraud provision, section 10(b) of the Securities Exchange Act of $1934,{ }^{115}$ a private plaintiff must demonstrate that the lender was actually aware of the fraud.116 Evidence of extensive lender involvement in a real estate development is not sufficient to create liability; indeed, the development of a scienter requirement in federal securities law argues persuasively for imposition of a similar knowledge requirement in private fraud actions under the analogous Land Sales Act. ${ }^{117}$

It is less clear whether a construction lender might still be considered a "controlling person"118 and thus be held liable for misleading information in registration statements under the Securities Act of 1933. ${ }^{119}$ A simple test for controlling person status and liability has so far eluded the courts; ${ }^{120}$ thus, securities litigation in a real estate context may indeed implicate construction lenders who effectively control a builder's transactions in certain circumstances. ${ }^{121}$ Yet, here too, something more than mere lender participation in the development project seems to be required in order for liability to attach. The exculpatory language in section 15 of the 1933 Act shields a "controlling person" from liability where he or she "had no knowledge of or reasonable grounds to believe" in the existence of a misstatement..$^{122}$ This language seems to require awareness of the violation as a precondition to liability, except where ignorance is due to a failure to carry out a reasonable duty of inquiry. ${ }^{123}$

\section{Evaluation}

\section{A. Existing Theory}

The extent of indirect construction lender liability thus seems to remain fairly limited. Common law liability for structural defects seems now to be confined to a rather narrow and perhaps extreme set of circumstances. This is so despite the potentially broad implications of the California Supreme Court's decision in Connor

11515 U.S.C. $\$ 78 \mathrm{j}$ (b) (1976).

116 Ernst \& Ernst v. Hochfelder, 425 U.S. 185 (1976).

117 See text accompanying notes 146-54 infra.

11815 U.S.C. $\$ 770$ (1976).

11915 U.S.C. $\$ \$ 77 \mathrm{k}, 771$ (1976).

120 See U. PA. Comment, supra note 97, at 1352-53.

121 See Douglas-Hamilton, Creditor Liabilities Resulting from Improper Interference with the Management of a Financially Troubled Debtor, 31 Bus. LAw. 343 (1975) [hereinafter cited as Douglas-Hamilton].

12215 U.S.C. $\$ 770$ (1976).

123 See U. PA. Comment, supra note 97, at 1353. 
v. Great Western Savings \& Loan Association.124 As for lender liability under the Interstate Land Sales Full Disclosure Act, the courts differ as to the appropriate standard. The willingness of the court in Timmreck $v$. Munn ${ }^{125}$ to infer knowledge of fraud from a sufficient degree of lender involvement in a development project could expose many financial institutions to suits and out-ofcourt settlements. The competing standard, requiring actual proof of lender awareness of fraudulent representations, ${ }^{126}$ is understandably less worrisome to construction lenders. Liability under the federal securities laws is too uncertain to forecast with any confidence, since courts are only now addressing the antecedent question of the securities laws' applicability to real estate transactions. However, previous securities litigation in a context other than real estate seems to have foreclosed the possibility that mere participation in a development, even though substantial, would be sufficient to make a lender liable.

With the limits of construction lenders' indirect liability under current law thus identified, the question arises whether the results are satisfactory. The practical effect of the participation criterion, by insulating nearly all construction lenders from liability, has been disastrous to purchasers of defectively constructed homes. Meanwhile, construction lenders would be more concerned with the possibility of statutory liability. Although no trends have yet developed, the recent decisions seem to assume that in certain circumstances lenders could be sued under the Land Sales Act as aiders and abettors of fraud. ${ }^{127}$ Courts have not yet sufficiently identified what those circumstances might be. Lenders justifiably might be especially uneasy about the apparent lack of an "actual knowledge" requirement in Timmreck's Land Sales Act decision. Indeed, that opinion seems to resemble Connor and could lead courts in statutory cases, as in the common law cases, to hold that extensive lender participation suffices for imposition of liability. Such a formula, however, provides lenders too little protection in the Land Sales Act cases and furnishes them too much protection in the construction defects cases.

12469 Cal. 2d 850, 447 P.2d 609, 73 Cal. Rptr. 369 (1968).

125433 F. Supp. 396 (N.D. IIl. 1977).

126 See text accompanying notes 86-92 supra.

127 Although only Timmreck v. Munn, 433 F. Supp. 396 (N.D. M1. 1977), has gone so far as to uphold such a claim, both Bartholomew v. Northampton Nat'l Bank of Easton, 584 F.2d 1288 (3d Cir. 1978), and Fuls v. Shastina Propertles, Inc., 448 F. Supp. 983 (N.D. Cal. 1978), implied in dicta that a lender who knowingly abetted a developer's fraud could be held liable, despite the Land Sales Act's express applicability only to "developers" and "agents." 
To correct these inadequacies, this Comment proposes a new framework for understanding and assessing indirect liabilities of construction lenders. This discussion begins with the premise that the levels of lender participation and extent of economic benefit are largely irrelevant to a sound theory of indirect lender liability. Such a theory can be based only on a direct assessment of the capacity of the construction lender to control the development enterprise. Since indirect liability is imposed on the lender solely because of its failure to detect and correct the developer-borrower's negligent construction or fraudulent misrepresentations, this liability can be justified only if the lender is in fact in a position to undertake such supervision.

The participation criterion currently used by the courts depends upon two invalid assumptions: first, that participation increases economic benefit, and, second, that participation and economic benefit translate into control over the construction project. The thesis has been stated as follows:

It is difficult to find a point between protective restrictions and total creditor supervision at which control responsibilities should be imposed. A reasonable and defensible conclusion would be that, once the creditor is not satisfied with simply insulating himself from the risk of loss of capital and interest, and instead insists upon affirmative participation in the entrepreneurial effort being financed, he has, in Prosser's terms, entered into a relationship whose expected extraordinary economic benefit justifies the requirement of special obligations.

Moreover, the fact that the creditor has been able to obtain affirmative participation is perhaps the truest evidence of his control over the financially-beleaguered debtor. In this sense, the proper scope of the securities law should be virtually identical to that recently developed by the common law. ${ }^{128}$

Although these commentators reviewed the Connor decision, they did not otherwise direct their attention to construction lenders. However valid in other contexts, these conclusions cannot be applied soundly to the construction lending industry.

The suggested distinction between defensive and affirmative participation is difficult to delineate in that industry. According to some accounts, savings and loan associations often view con-

128 Bartlett \& Lapatin, supra note 1 , at 655 (citations omitted). 
struction loans only as necessary preliminaries to obtaining profitable long-term mortgages from the builder's customers. ${ }^{129}$ The savings and loan associations are said to derive their profit primarily from the interest on these long-term "end loans." If this sort of single profit calculation is in fact commonly undertaken by financial institutions, it makes little sense to characterize, as did the Connor court, agreements linking construction and home purchase loans as affirmative participation. Indeed, it is also difficult to perceive how such linkage enhances a lender's control over the developer's day-to-day operations: while it may extend the period of the lender's involvement in the project, it does not necessarily entail additional inspection or supervision. The single profit calculation theory thus suggests that a court misdirects its energies when, as in Callaizakis v. Astor Development Co., ${ }^{130}$ it focuses on whether the lender was soliciting end loans: this is an insignificant fact. Such treatment indicates both a misunderstanding of the lenders' decisionmaking process and a confusion of the concepts of economic benefit and participation.

Connor involved, of course, the additional element of profit from the land warehousing scheme. It is perhaps appropriate to speak of unusual participation and economic benefit where, as in Connor, the lender can expect a return on its investment at two stages of the transaction. However, the presence of a warehousing scheme or other lucrative arrangements alone says little about a lender's ability to prevent the developer's allegedly culpable conduct. A lucrative deal may simply reflect a lender's sheer economic power. Just as a supplier of materials, because of its monopolistic position, is sometimes able to exact an extraordinary economic benefit from a transaction with the developer, so a lender possessed of a superior bargaining position might well secure a substantial return on its investment. Such was Great Western's fortune in Connor.

This ability to reap a significant financial benefit from a transaction results from economic control of the marketplace. Yet, this marketplace influence must be distinguished from control sufficient to justify lender liability. By introducing notions of economic benefit and participation into the liability equation, courts

129 Lender Liability for Construction Defects, 5 R. Prop. Proв. Tr. J. 495, 498 (1970); U. CHr. Comment, supra note 25, at 744. The Comment's findings were based on extensive interviews with Chicago savings and loan associations. They also indicated widespread use of a penalty system whereby a builder-borrower was penalized unless all or a certain percentage (usually around 70\%) of his purchasers obtained mortgage funds from the construction lender. Id. 744 n.37.

1304 ll. App. 3d 163, 280 N.E.2d 512 (1972). 
and commentators have unearthed, not surprisingly, only such marketplace influence. Chief Justice Traynor concluded in Connor, for example, that, because of its ability to secure a $\$ 30,000$ capital gain from the warehousing scheme as well as the right of first refusal on long-term home purchase mortgages, ${ }^{131}$ Great Western "controlled" the Conejo Valley project. These provisions of Great Western's construction loan agreement reflect, however, only a disparity of bargaining power. This influence does not translate into a real capacity to supervise the allegedy culpable conduct of the home developer. If a construction lender is properly to be held liable for failure to exercise reasonable care in its oversight of development operations, whether actual construction or sales efforts, the capacity for exercise of such supervision must be demonstrated. This capacity is not established by proof of economic benefit or lender participation, the twin indicia of marketplace influence. ${ }^{132}$

A review of circumstances in which courts have recognized creditor control of debtors in nonconstruction contexts supports this view. One commentator has identified three sources of such control: voting control, management control, and financial domination. ${ }^{133}$ The first two sources, ownership of voting stock sufficient to select a majority of a corporation's directors, and clauses in financial agreements giving a creditor the power to make management appointments, have not appeared in the construction lending context. Yet, in both instances, there clearly exists the capacity, through appropriate board or management appointments, to supervise the allegedly culpable conduct of the borrower. These judicial determinations of control are consistent, therefore, with this Comment's assertion that liability must be grounded upon something other than sheer economic power. Nor is the last contention defeated by the conclusion of this commentator that,

131 See text accompanying notes $29 \& 30$ supra.

132 Two distinctions must be noted between the ability to secure a substantial profit in the transaction and the capacity for supervision of the activities of the other party to the transaction. Profit can accrue although the relationship between the parties lasts but a short time. In contrast, the capacity for supervision requires at the minimum a continuing relationship. If the negligence of the party to be supervised occurs after the relationship has been terminated, it makes little sense to argue that supervision is practicable: under such an argument, a party becomes responsible potentially for the acts of each of its past customers or clients. Even this continuing relationship, however, is not sufficient unless the supervising party is in a position, in terms of expertise and capacity for physical inspection, to oversee the other's conduct. Once again, an individual or business can realize profit in the transaction despite the absence of any expertise in the business of the other party. Liability based on negligent supervision cannot justly be imposed, however, absent the above factors.

133 See Douglas-Hamilton, supra note 121 , at $344-45$. 
in some cases, "financial domination" of a debtor also may confer control on a creditor. The decisions cited to support the equation of control and financial domination simply do not involve claims of lender liability. ${ }^{134}$

\section{B. An Alternative Framework}

\section{Overview}

The foregoing discussion illustrates that lender participation and economic benefit should not be the critical factors in determining whether lender liability is justified. The remainder of this Comment outlines an alternative framework for understanding and assessing indirect liabilities of construction lenders. The underlying premises of the proposed framework already have been developed. A lender's capacity for control of the developer's negligence or fraud must be established before liability resting on careless supervision can be imposed. ${ }^{135}$ A court should consider whether current lender routines indicate that supervision of a particular aspect of the developer's conduct is feasible. This feasibility must be viewed in a sense as a threshold requirement, for without evidence that a lender could have acted otherwise, there can be no fault or blameworthiness, and one would have ventured as a result into the realm of strict liability. ${ }^{136}$

Proof that the proposed oversight can be feasibly undertaken establishes a necessary but insufficient condition for liability. Once

134 In several instances, the issue was purely jurisdictional-whether a regulatory agency had to approve a given transaction turned on whether the transaction would establish control over a regulated party. See Toolco-Northeast Control Case, 42 C.A.B. 822 (1965); Watt Transport, Inc., 338 I.C.C. 338 (1971); Canadair Ltd. v. Seaboard World Airlines, Inc., 43 Misc. 2d 320, 250 N.Y.S.2d 723 (N.Y. Sup. Ct. 1964). In the remaining case, liability was imposed, but not on a creditor. See In re Walston \& Co., 7 S.E.C. 937 (1940) (brokerage firm found liable by SEC for failure to disclose in its registration statement the control status of its primary creditor). Given the unusual posture of these cases, their finding of control with no apparent attention to the issue of feasibility of actual supervision is neither surprising nor damaging to this Comment's argument.

135 For a brief consideration of the opportunity for control in the context of lender liability for construction defects, see U. CHI. Comment, supra note 25, at 757-58. See also Harper \& Kime, The Duty to Control the Conduct of Another, 43 YAIE L.J. 886 (1934).

136 Such an alternative must be recognized, of course. Yet, it is one which should be explored only with an adequate understanding of its potential impact on the housing industry. Even the more limited theory of liability proposed by this Comment, which affords the lender some measure of self-protection, nonetheless threatens to raise interest rates on construction loans and drive small-scale developers out of the housing industry. Strict liability would more severely constrict the industry. Until further empirical data on market impact is available or until it is proven that a more limited remedy will not suffice, a theory grounded upon fault is preferable. 
this threshold is passed, courts should investigate means by which the construction lender might reduce the risks or spread the costs of liability for negligent inspection. If no self-protective devices are identified, lender liability may be too drastic. The lender's presence in the litigation is likely to be a function of the builder's insolvency; thus, the construction lender would be potentially liable for the entire amount of damages resulting from an incident for which it was only partially responsible. Before such a severe penalty is imposed, a court should determine whether the lender can secure itself against the eventuality of the builder's insolvency: Are there mechanisms by which it can insure the developer's compliance with quality standards? Can the costs of liability be spread? If the lender is left to bear the costs of liability without the benefit of self-protective devices, the consequences may render construction-lender liability inappropriate.

The other side of this argument is that, as between a negligent lender and a home or lot purchaser, the former is "more blameworthy." This is an effective rebuttal in the theoretical case of a "closed" two-party transaction, but here the market impact demands attention. The examination of self-protective devices is closely related, therefore, to a final question to be posed by a court under the proposed framework: What impact will construction-lender liability have on the housing industry? Even where the lender has some means of self-protection at its disposal, imposition of liability may lead to changes in lending policies which in turn affect the housing industry. Where no devices exist to reduce or spread the burden of liability, the result would certainly be an increase in interest rates and thus a general constriction of the housing market. The certainty and gravity of such consequences mandate legislative rather than judicial determination of lender liability policy. However, where both feasibility of oversight has been established and constriction of the housing market at least can be minimized by some lender control over the extent of its losses, then the balance weighs in favor of relief for the defrauded buyer.

This three-part test for assessing indirect lender liabilityfocusing on feasibility of oversight, availability of self-protective devices, and potential market impact-leads to more sensible results than those courts have obtained under the participation criterion..$^{137}$ Applying this alternate theory to the primary types of liability claims, this Comment recommends a significant potential for lender 
liability in the construction defects disputes, but would restrict liability in the fraud cases to a narrow set of circumstances. In short, the spirit of Connor should be revived and the broad implications of Timmreck rejected.

\section{Feasibility of Supervision}

Whether it is feasible for a lender to inspect a site for defective construction can be best answered by considering the customary procedures and appropriate concerns of a construction lender. The lending institution's primary responsibility is protection of its underlying security interest. Its loan normally is calculated as a percentage of the appraised value of the improved land. So long as the land and building can be repossessed and sold for an amount equal to the face value of the loan, the lending institution has averted a losing transaction. To insure that the security interest has attained a value at least equal to that on the face of the loan, lender routine currently includes at least a minimal inspection of the construction site. This inspection verifies that loan funds are being disbursed on a schedule in accord with the rate and amount of construction. ${ }^{138}$ There is evidence that, in practice, inspectors often investigate the quality of workmanship. ${ }^{139}$ The response of courts and lenders has been, of course, to emphasize that such inspection is undertaken for the latter's own protection and not for that of home purchasers. ${ }^{140}$

138 See Practictng Law Institute, Construction Financing 103-14 (1977); Livingston, Current Business Approaches-Commercial Construction Lending, 13 Real Prop. Prob. Tr. J. 791 (1978); U. Crr. Comment, supra note 25, at 744-48. 139 See Lubell, supra note 25, at 364; U. Cer. Comment, supra note 25, at 747-48. The author of the latter article found on the basis of extensive interviews with Chicago area loan officers that a vital function served by site inspection was to insure that adequate and reasonable workmanship was being achieved by bullderborrowers. The loan associations required inspectors to check as many as 107 construction items, ranging from foundation and framing of steel beams and floors to such minor items as storm doors, interior painting, and ornamental iron. Id. 748 n.55.

Lending institutions certainly have the bargaining power and legal capability to control construction quality. The terms of the loan agreement between lender and builder often empower the former to insist on quality workmanship as a condition for continued payment. A model loan agreement recommended for use by lenders' attorneys contains the following provision:

Where any ... substantial defective or unworkmanlike labor or materials are being used in the construction of the Building ...., the lender shall have the right to give notice to correct the condition and, if this is not accomplished within 30 days, Lender may immediately order stoppage of construction on that portion affected and demand that the condition be corrected.

Practicing Law Institute, Construction Financrisg 363 (1977). This model agreement also indicates that a lender may stop payment if the builder uses materials not in accordance with the plans and specifications. Id. 355 .

140 See text accompanying notes $43-46$ supra. 
Still, one questions the necessity and appropriateness of that distinction. Given the strong public interest in preventing faulty workmanship and protecting consumers who frequently are not on hand to observe the early stages of construction, courts could justifiably rely upon existing inspection procedures as evidence that supervision for the benefit of third parties can be practicably undertaken. It would not be the first time that tort law has imposed a duty of care on third parties where feasible and where public policy demands. ${ }^{141}$ Such a duty of care would not extend to all construction defects but only to those discoverable by a reasonably efficient and thorough site inspection. Most gross structural defects would, therefore, be involved; minor defects, however, would not implicate a lender's exercise of due care. ${ }^{142}$ Similarly, if a lender could reasonably be expected to discover the use of substitute materials not in accordance with the agreed-upon plans and specifications, then failure to discover such substitution might expose the lender to joint liability. ${ }^{143}$ It remains important, however, to dis-

141 "If the conduct of the actor has brought him into a human relationship with another, of such character that sound social policy requires either some affirmative action or some precaution on his part to avoid harm, the duty to act or take the precaution is imposed by law." Harper \& Kime, The Duty to Control the Conduct of Another, 43 YALE L.J. 886, 886 (1934).

Cf. U. CHa. Comment, supra note 25 , at 757 , which proposes lender liability contingent "upon the closeness of the relationship between the parties and upon the existence of a reasonable opportunity to control the harmful conduct." Id. (emphasis in original) (citations omitted). To the extent that a "close relationship" requirement threatens to resurrect the participation criterion, it should be rejected so as properly to fix the courts' attention exclusively on where it properly belongs: the threshold issue of control. If a lender's "reasonable opportunity to control" is to be measured on a case-by-case basis, social policy and consumer protection would be best served by the creation of a rebuttable presumption that the opportunity to control is reasonable where lenders check on the progress of construction in order to disburse loan funds. This presumption would correspond to the premise of this Comment, that construction lenders are not being required to perform tasks not already regularly undertaken; the law simply imposes sanctions for careless execution.

142 The policy arguments for indirect lender liability to consumers are strongest when the defects are present in the home's foundation. These are often the most serious construction defects and frequently can be discovered only during the early stages of construction. Further, even those purchasers who are able to employ architects to inspect the builder's product may be unable to detect them, if negotiations begin after construction is in an advanced stage or is completed. See U. Crr. Comment, supra note 25 , at 752 .

Because the lender's duty of care would be limited to averting gross defects and those otherwise detectable by a customary inspection, such a proposal would not expose lenders to products liability suits for injuries caused by defectively manufactured items installed in the home. While there remains a possibility that defective construction might result in personal injury, see Perez v. United States, No. 78-1107 (1st Cir. Mar. 15, 1979), the defects for which a lender may be held responsible are more likely the kind which cause property damage and a reduction in the value of the consumer's investment.

143 See note 139 supra. The model construction loan agreement recommended in Practicing Law Institute, Construction Financing 355 (1977), contains a 
tinguish such liability, grounded in the lender's negligence, from the doctrine of vicarious liability in which the lender's conduct is irrelevant. ${ }^{144}$

With respect to a construction lender's statutory liability, the threshold requirement of feasibility rarely will be satisfied. Claims against construction lenders under the Land Sales Act and the securities laws arise in connection with fraudulent misrepresentations or omissions of material facts as to the builder's financial condition or the nature of the proposed community. Absent actual notice of fraud, it is impractical to demand lender supervision of the developer's sales operations or rigorous scrutiny of his official filings. 145

The issue of feasibility is most appropriately addressed in terms of the varying standards of Timmreck $v$. Munn ${ }^{146}$ and Bartholomew $v$. Northampton National Bank of Easton..$^{147}$ Recall first that indirect liability is grounded in a theory of supervision. In the common law context, the construction lender could be liable if it failed to recognize and correct the developer's gross construction errors. ${ }^{148}$ In the statutory context, the lender is being called upon to recognize and arrest any fraud by the developer. Timmreck and Bartholomew differ as to the point at which that duty to supervise selling operations and scrutinize official filings is activated. In Bartholomew that point is reached when the construction lender acquires actual knowledge of the developer's fraud. ${ }^{149}$ The broad language of Timmreck, on the other hand, implies that the duty to supervise is activated at an earlier point: whenever the lender has a substantial economic interest and involvement in a project and, therefore, can be presumed to have constructive knowledge of the developer's fraud. Participation and not actual knowledge seem to be key, at least for purposes of upholding the plaintiffs' complaint. ${ }^{150}$

provision empowering the lender to insist upon the use of agreed-upon materials: "If building shall not be constructed, completed, and equipped strictly in accordance with the Plans and Specifications, ... . then Lender at its option may terminate the Agreement."

144 See W. Prosser, HandBook of tHe LAw of Torts 458-59 (4th ed. 1971); U. Chr. Comment, supra note 25 , at 757 . Vicarious liability arises frequently when losses have been caused by employees' torts which, as a practical matter, are certain to occur in the conduct of the employer's enterprise.

145 See text accompanying notes 151-54 infra.

146433 F. Supp. 396 (N.D. III. 1977).

147584 F.2d 1288 (3d Cir. 1978).

148 See text accompanying notes $138-44$ supra.

149 See text accompanying notes 86-90 supra.

150 See text accompanying notes 79-90 supra. 
The result in Timmreck may be correct since the lender there had allegedly engaged in the planning of the project and drafting of the required filings. Such circumstances directly implicated the lender as a protagonist in the fraud, not merely as a negligent supervisor. Yet, if Timmreck is not read carefully and limited to its facts, it could be construed as imposing constructive knowledge of fraud and, therefore, an affirmative duty to arrest fraud on any lender who participates extensively in a development project. It becomes imperative, then, according to the framework proposed in this Comment, that courts identify the circumstances in which lender supervision of selling operations and investigation of official documents is feasible.

A duty to inquire and supervise is feasible only at the point at which a lender actually receives evidence of a violation. One need only consider the practical implications of the alternative constructive knowledge standard; if, as in Fuls v. Shastina Properties, Inc. ${ }^{151}$ a salesman fraudulently represents that lots are in short supply and that investment in them will appreciate rapidly, such information might be imputed to a lender actively involved in the project but possessing no actual knowledge of the violation. Active lenders could avoid liability under such a standard only by continually monitoring the developer's day-to-day selling operations. However, a lender cannot be expected to employ one or more individuals to insure that a developer maintain an acceptable level of accuracy in his official and informal dealings.

In contrast, the more limited actual knowledge requirement of Bartholomew yields an acceptable result. Any duties imposed on lenders under the proposed framework must satisfy a minimum feasibility requirement. It appears reasonable to require that a lender, once possessing actual knowledge of fraud, discontinue all dealings with the developer and notify appropriate parties of its findings. Such a standard does not obligate a lender to monitor daily sales operations or scrutinize every sales brochure and document for misrepresentations or omissions. Where a lender, in the ordinary course of dealing, gains access to any evidence of fraud, it at that point becomes responsible for investigating the matter before conducting any further business with the borrower.

It is important to avoid overstating this responsibility. Perhaps its limited nature can be made clearer by reconsidering the most likely scenario. Before committing to a loan, any prudent lender will demand some information as to the builder's financial condi-

151448 F. Supp. 983, 986 (N.D. Cal. 1978). 
tion, the general outline of the proposed community, and its acceptability to local authorities. ${ }^{162}$ Such pieces of information are critical to the loan decision..$^{153}$ Similarly, financial institutions, such as those in Timmreck, Bartholomew, and Shastina Properties, which purchase land sales contracts from the developer at a discounted price, will exercise these precautions. When this preliminary information, currently employed by lenders in their decisionmaking process, indicates that a developer's promises grossly overreach his financial capacity, the lender is alerted to the possibility of fraud. In effect, it has gained, through its ordinary course of dealing, actual knowledge of fraud. If the lender proceeds with the loan despite the information indicating a disparity between promise and reality, it properly may be held liable as an aider and abettor of fraud under the standard enunciated in Bartholomew. ${ }^{154}$

The foregoing outlines the scenario in which actual knowledge of fraud is most likely to arise. It represents the limited sense in which a lender's inspection for a developer's fraudulent misrepresentations may be feasibly undertaken. However, an expansion of this scenario of actual knowledge obtained in the course of normal loan-commitment or financing decisions to a requirement of broader, ongoing supervision of sales operations, violates the feasibility threshold imposed by this Comment's framework and, thus, precludes indirect lender liability. Such a result is not inconsistent with the earlier conclusion that lender liability under the common law for construction defects should be expanded. ${ }^{155}$ The premise of that discussion was that lenders currently make periodic site inspections and thus are not being required to undertake entirely for-

152 See Practicing Law Institute, Construction Financing 51-55 (1977); Livingston, supra note 138.

153 For example, such information bears upon the probability that the project will yield profitable end loans and that amounts due under the land sales contracts will be easily collected. Information concerning the developer's promotional package is critical to any appraisal by the lender of the value of the land securing the sales contract. The purchase price of a single lot can be significantly affected by the attractiveness of any promised amenities. A lot otherwise worth $\$ 5,000$ may sell for $\$ 10,000$ with the understanding that it soon will border upon lakes, clubhouses, and ski slopes. Should such amenities fail to materialize, the lot will, when resold after foreclosure, yield only the lesser original value of $\$ 5,000$. To secure itself against such an eventuality, a prudent lender can be expected, therefore, to inquire with sufficient thoroughness into a developer's reliability as well as the probability of project completion. See U. Crr. Comment, supra note 25, at 745.

154 Recall that the court in Connor criticized the defendant lending institution for ignoring ominous signs of thin capitalization in the developer-borrower's financial statement. See note 32 supra.

155 See text accompanying notes 138-44 supra. 
eign responsibilities; in contrast, expansion of lender liability for aiding and abetting a developer's statutory fraud would entail significant expansion of a lender's activities far beyond present custom.

\section{Lender's Self-Protection}

The scope of a lender's duty should not depend on present custom alone. Any theory of indirect lender liability should undergo a cost analysis as well. One must inquire if the lender is in a position, once it becomes aware of a developer's fraud or negligence, to enforce compliance by the borrower and thereby restrict the number of liability claims at minimal cost to itself. Alternatively, one must consider if there are market mechanisms by which the construction lender can spread the costs of liability.

Self-protective devices do exist by which a lender can shoulder its already restricted liability for a developer's fraud. If the institution actually gains knowledge of a violation sufficiently early, it can reject the builder's loan application. If discovery comes after a portion of the construction loan funds have been disbursed, the lender may be able to suspend further "progress payments" until the developer has provided evidence of compliance or has otherwise satisfied his customers. ${ }^{156}$ On the other hand, a finance company which merely purchases discounted land sales contracts arguably has less leverage over the builder. Once the contracts are purchased, the relationship between builder and finance company is at an end. The finance company can threaten to discontinue future dealings, but this is certainly not likely to induce a "fly-by-night" developer to fulfill his commitments.

Control over progress payments also enables construction lenders to minimize their burdens of liability for faulty construction. By making such installments contingent on satisfactory workmanship at each stage of construction, commercial lenders can certainly encourage builder compliance with quality standards and insure that errors are corrected. At minimal cost to themselves, the lenders may thereby reduce the threat of future liability. ${ }^{167}$

156 Practicing Law Institute, Construction Financing 78-79 (1977).

157 See U. CHI. Comment, supra note 25 , at 748 , for the view, based on a Chicago survey, that some loan associations uniformly withhold ten percent of the loan fund until the purchaser has moved into the completed house and has found it satisfactory. Such "reserve accounts" are also a common device to secure lenders against mechanics' liens, see generally Comment, Mechanics' Liens and Surety Bonds in the Building Trades, 68 YAI.E L.J. 138 (1958); however, no further evidence has been found to suggest that their use for purposes of ensuring purchaser satisfaction is widespread. 
Of equal significance is the ability of a loan association to increase interest rates and thereby procure enough insurance to cover damages incurred in suits by purchasers of defectively constructed homes. Its transaction volume should enable the lender to spread the cost of insurance widely enough so as to minimize the burden on itself and any individual borrower. ${ }^{158}$ The cost of compensating victims of construction defects would thus be spread among all purchasers. As the law currently stands, such victims often find themselves without remedy if the developer becomes insolvent after completion of the home but before a money judgment can be secured. The construction lender emerges as the only viable defendant.

In the analogous context of consumer goods transactions, courts have acknowledged the superior cost-spreading ability of finance companies: they have responded by permitting defrauded customers to interpose contractual defenses to claims filed by large-scale creditors who had purchased the consumers' installment contracts. ${ }^{159}$ This doctrine, which applies even to defenses relating to the quality of the goods, has focused on the finance company's ability to protect its own interests. ${ }^{160}$ In Mutual Finance Co. v. Martin, ${ }^{161}$ for example, the finance company retained in a "reserve account" part of the purchase price of a note. That amount was payable to the seller only upon the buyer's completion of his payments. This "holding back" of part of the purchase price was viewed by the court as sufficient protection to warrant affirmance of the buyer's quality defense. It could be argued, of course, that there is a substantial difference between susceptibility to defenses and the affirmative liability being proposed in this Comment. ${ }^{162}$ Yet, even here, the gap seems to be narrowing. One commentator has noted

158 See S. CAL. Comment, supra note 11, at 370-71; U. CHI. Comment, supra note 25 , at 754 .

159 The seminal case in this area is Commercial Credit Corp. v. Orange County Machine Works, 34 Cal. 2d 766, 214 P.2d 819 (1950); see also Kaw Valley State Bank and Trust Co. v. Riddle, 549 P.2d 927 (Kan. 1976). For support of this development, see, e.g., Countryman, The Holder in Due Course and Other Anachronisms in Consumer Credit, 52 TEx. L. Rev. 1 (1973) [hereinafter cited as Countryman]; Rosenthal, Negotiability-Who Needs It?, 7 I ColuM. L. REv. 375 (1971); Comment, Implied Gonsumer Remedy Under FTC Trade Regulation Rule-Coup de Grace Dealt Holder in Due Course?, 125 U. PA. L. Rev. 876 (1977) [hereinafter cited as Coup de Grace?]. $890-91$.

160 See Countryman, supra note 159, at 10; Coup de Grace?, supra note 159, at

16163 So. 2d 649 (Fla. 1953).

162 See U. Crr. Comment, supra note 25, at 750. 
that a recent Federal Trade Commission regulation ${ }^{163}$ does not restrict a consumer's recovery to amounts paid to the finance company after the latter's purchase of the installment contract; rather, he contends that, "in a proper case, a buyer can obtain all payments made to the retail seller as well as to the finance agency in an action brought against the finance agency alone." ${ }^{164}$ This trend toward affirmative liability of finance companies supports the validity of the analogy drawn as to measures of self-protection available to construction lenders and finance companies.

\section{Market Impact}

A detailed forecast of the economic impact of constructionlender liability on the housing industry is beyond the scope of this Comment, though such an empirical study would be valuable to courts, legislatures, and commentators. This Comment has asserted, however, that extent of market impact may be a function of the lender's capacity for self-protection. Where no such capacity appears, the inevitable rise in interest rates would most likely constrict the housing market to an unacceptable degree. The circumstances of lender liability recommended in this Comment should not have such severe consequences since, as discussed above, ${ }^{165}$ construction lenders are in a position to reduce the risks and spread the costs of liability. Indeed, by passing the cost of insurance on to builders and ultimately consumers, a lender spreads it not only numerically but temporally as well; since mortgages are paid off over time, even significant price increases should not appreciably inflate monthly payments..$^{166}$

Lender liability for defective construction may, of course, have some adverse consequences. Interest rates will rise somewhat and developer-borrowers will be screened more conservatively; the effect may be to drive smaller, less financially stable developers from the in-

163 FTC Preservation of Consumers' Claims and Defenses, 16 C.F.R. $\$ 433.2(a)$ (1977). This regulation requires every contract which combines the sale of consumer goods with the sale of credit to contain the following clause:

NOTICE

Any holder of this Consumer Contract is subject to all Claims and Defenses which the Debtor Could Assert Against the Seller of Goods or Services Obtained Pursuant Hereto or with the Proceeds Hereof. Id.

164 Reitz, Consumer Credit Protection Under the Magnuson-Moss WarRANTY ACT 124 (1978).

165 See text accompanying notes 157-58 supra.

166 See U. Crr. Comment, supra note 25 , at 756. 
dustry. ${ }^{107}$ While this may at first seem beneficial, it may, in time, diminish price competition within the industry and also skew construction towards larger apartment and townhouse complexes and away from single units and smaller apartments. ${ }^{168}$ Despite these ramifications, however, the balance in these cases should still fall in favor of relief for the home purchaser. Buying a home is generally the largest investment a family makes. A latent structural defect leading to such serious damage as a cracked foundation could prove financially ruinous to many families unless the loss can be shifted and spread.

\section{Conclusion}

This Comment has reviewed the current potential for indirect construction-lender liability and has noted the assumptions underlying imposition of such liability. Finding this conceptual blueprint practically and theoretically inadequate, it has advanced an alternative framework for understanding and assessing the validity of liability claims. At a minimum, feasibility of lender supervision of the developer's allegedly culpable conduct must be established before liability for negligent supervision may be imposed. When this threshold requirement is applied to statutory claims, lender investigation into a developer's sales operations and official filings rarely appears practical. Construction lenders should not, therefore, be held responsible for arresting a developer's fraudulent misrepresentations or omissions until such time as they receive evidence of a violation. Where the crucial threshold of feasibility is passed, as with lender inspection of construction sites, attention must then be directed to the matter of costs. The availability of sufficient means of lender self-protection can so minimize industrywide and individual costs that lender liability is a justifiable solution to the problem of defective construction.

167 See Lubell, supra note 25, at 366; U. CHr. Comment, supra note 25, at 754 . 108 See Lubell, supra note 25, at 165; S. CAL. Comment, supra note 11, at 371. 